\title{
Revista Brasileira de Medicina de Familia

\section{As potencialidades da personalidade-alma na reabilitação da linguagem e do pensamento: um estudo transdisciplinar de caso no SUS}

\author{
Renata Paes de Barros ${ }^{1,2}$ \\ ${ }^{1}$ SUS, Prefeitura de Descalvado/SP. \\ ${ }^{2}$ Grupo de Pesquisa Fundamentos do Rosacrucianismo e Desenvolvimento Humano numa Perspectiva \\ Transdisciplinar da Universidade Rose-Croix Internacional (URCI), Núcleo São Paulo. \\ Email: renatapaesdebarros@hotmail.com
}

Introdução: A clínica fonoaudiológica dentro do SUS, no interior paulista, é ainda muito pautada por um referencial reducionista, próprio da medicina convencional. A Antiga e Mística Ordem Rosae Crucis, AMORC, é uma escola do esoterismo ocidental, que veicula a Tradição Rosacruz. Nesta Tradição, "personalidade-alma" é a identidade psíquica da pessoa, uma "manifestação objetiva da reação individual à parte integrante da Alma Universal". Este "Eu Interior" é dotado de grande potencial que pode ser atualizado à medida que se eleve a consciência de modo a torná-la mais sensível aos influxos da Alma. (LEWIS, 1988). O processo de desenvolvimento, ou evolução através das existências propicia à pessoa a transcendência dos níveis de percepção e de realidade (NICOLESCU, 2000) de forma a promover sua evolução. Na atuação clínica em saúde, a abordagem sócio-interacionista (VIGOSTSKY, 2007) aliada à compreensão mística da personalidade-alma possibilita uma prática clínica ampliada orientada para a reorganização dos processos psíquicos. Objetivos: Contribuir para uma Clínica Fonoaudiológica Ampliada no SUS, a partir de uma leitura Integrativa de conhecimentos tradicionais e contemporâneos. Método: Estudo de Caso com enfoque na metodologia de pesquisa social do tipo participante (RICHARDSON, s.d.), isto é, onde pesquisador (observador) e sujeito (observado) interagem no mesmo contexto a partir de uma realidade construída entre ambos, num campo fenomênico de significado comum. Resultados: O paciente foi capaz de recuperar sua condição de estudante a partir do estabelecimento de uma nova consciência de si promovida pela autotranscendência das limitações impostas pelo quadro clínico. Conclusão: Os resultados sugerem ser a abordagem transdisciplinar adequada para o estabelecimento de pontes dialógicas entre os conhecimentos tradicionais e perspectivas contemporâneas de conhecimento.

Palavras-chave: Psicologia. Linguística. Pensamento. Reabilitação. Integração de Sistemas. 